\title{
"Periferias" móveis: (homo)sexualidades, mobilidades e produção de diferença na cidade de São Paulo*
}

\author{
Bruno Puccinelli** \\ Ramon Pereira dos Reis***
}

\section{Resumo}

Este artigo é parte de um exercício etnográfico conjunto com vistas a problematizar noções de "periferia", ou do que é "periférico", articuladas a determinados marcadores sociais da diferença presentes nas circulações de sujeitos que se autoidentificam pela via da masculinidade e da (homo)sexualidade. A partir de dois campos na cidade de São Paulo, discutimos as possibilidades de cruzar contribuições da geografia feminista para os estudos antropológicos urbanos e vice-versa, partindo principalmente da produção do espaço pelas circulações dos sujeitos.

Palavras-chave: "Periferias", (Homo)Sexualidades, Mobilidades, Disputas Socioespaciais

* Recebido em 23 de agosto de 2017, aceito em 15 de março de 2019.

* Pesquisador no Núcleo de Estudos sobre Marcadores Sociais da Diferença NUMAS, Universidade de São Paulo, São Paulo (SP), Brasil e da Rede de Estudos de Geografia, Género e Sexualidade Ibero Latino-Americana puccinelli.br@gmail.com / https://orcid.org/0000-0001-5007-1657.

*** Coordenador da Linha de Pesquisa Territorialidades, Produção Social das Diferenças e Diversidade Sexual e de Gênero do Grupo Interfaces (UFPA), Universidade Federal do Pará, Belém (PA), Brasil. ramonrei@gmail.com / https://orcid.org/0000-0001-8924-2097. 

mobilidades e produção de diferença na cidade de São Paulo

"Peripheries" in Movement: (Homo)Sexualities, Mobilities and Production of Difference in the City of São Paulo

\begin{abstract}
This article is part of a joint ethnographic exercise to problematize notions of "periphery", or what is "peripheral", articulated to certain social markers of difference present in the circulations of subjects who self-identify as masculine and (homo)sexual. Based on two fields of study applied to the city of São Paulo, we discuss the possibilities of crossing contributions from feminist geography with urban anthropological studies, and vice versa, mainly considering the production of space caused by the circulation of subjects.
\end{abstract}

Keywords: "Peripheries", (Homo)sexualities, Mobilities, Sociospatial Disputes. 
Podríamos preguntarnos no sólo qué verdad revela la metáfora espacial de centro-periferia, sino también qué disposición de conocimiento y poderes específicos encubre. Esto significa re-abrir ese espacio, re-pensar las viejas fórmulas y plantear nuevas preguntas (Chambers, 1995:113).

Este texto faz parte de um esforço conjunto com vistas a problematizar noções de "periferia"1, ou do que é "periférico", articuladas a determinados marcadores sociais da diferença presentes nas circulações de sujeitos que se autoidentificam pela via da masculinidade e da homossexualidade na cidade de São Paulo, não se tratando de uma aproximação ou definição única de como a identidade homossexual masculina ganha corpo nos contextos pesquisados. A partir disto, pretendemos dar conta da dinâmica social na qual tanto os pesquisadores quanto os interlocutores estão inseridos, dependentes da circulação produtora de si e outrem pela via de variados marcadores, tais como raça, classe e gênero, por exemplo, além do espaço ocupado na cidade e nos lugares de frequência. Desta feita, partimos de sujeitos e espaços em constante produção, seguindo as sugestões de Facchini (2008), Simões et al (2010), Agier (2011), Preciado (2010), França (2012) e Massey (2013). Levamos em conta exercícios de mobilidade pelo espaço urbano de modo a compreendermos significados e sentidos de "periferia" acionados durante nossas incursões etnográficas, que tomaram como pontos de partida a região do "centro antigo"2 - a Avenida Vieira de Carvalho e o Largo do Arouche -, e dois bares localizados nos bairros de "periferia" Itaquera e São Mateus, na zona leste.

1 Por uma questão estilística e a fim de destacar o questionamento de fixações espaciais, manteremos os termos "periferia" e "centro", bem como seus correlatos diretos, entre aspas, sob rasura, tal como propõe Hall (2005).

2 "Centro antigo" aqui se refere à forma como a região do entorno da Praça da República tem sido definida há algumas décadas. Contudo, em relação ao processo histórico de urbanização da cidade de São Paulo, é mais preciso considerar que este é o "centro novo" em relação ao triângulo formado pela Praça da Sé, Largo São Bento e Largo São Francisco. Sobre os processos de expansão e criação de novas centralidades paulistanas, ver Frúgoli Jr. (2000). 
Pretendemos dar ênfase e destaque à produção contingente de sujeitos, espaços, lugares, "centros" e "periferias", atentando para a forma diversa e transitória, mas também concreta $e$ dependente de certas fixações citadinas, constantes nos contextos pesquisados. Acreditamos que o nosso empenho em destacar como se constituem determinadas dinâmicas socioespaciais móveis e pontuais interfere diretamente no compromisso em qualificar movimentações, paragens e usos do espaço urbano, dos interlocutores e dos pesquisadores, além de salientarmos os processos de produção de etnografias crítico-reflexivas com vistas a questionar e/ou problematizar aspectos que, porventura, sejam percebidos como escopos auto-representativos (Cf. Marcus; Fischer, 2000 [1986]).

A confluência entre os posicionamentos e reflexividades em campo serve de fio condutor para a compreensão de uma metodologia alicerçada, por excelência, em uma perspectiva móvel, não exatamente na busca pela regularidade e intensidade de um possível exercício de movimento ou numa espécie de rastreio do que se faz em cada ir e vir, mas de que maneira determinadas feituras urbanas são (re)elaboradas seja para constituir e/ou nivelar identificações e pertencimentos, seja para demarcar de forma circunstanciada e dialógica a produção $e$ projeção de relações, contextos e conceitos. Isso nos aproxima, inclusive, do exercício teórico-metodológico intitulado "fazercidade" que foi proposto por Michel Agier (2015:483), no sentido de "pensar a universalidade da cidade fora de qualquer pretensão normativa, ou seja, segundo uma concepção ao mesmo tempo epistemológica e política", exprimindo de modo contundente uma reflexão acerca das relatividades nas análises do espaço (o não congelamento das estruturas) e do tempo (os contextos citadinos não são os mesmos conforme os tempos passam; tampouco são os mesmos os tempos de transformação).

No que se refere ao conceito de "periferia", para além de um exercício genealógico, é possivel reconhecer um investimento sobre o tema na antropologia e na sociologia urbanas produzidas em São Paulo, especialmente em Caldeira (1984, 2000); Zaluar 
(1985)33; Durham (1986); Magnani (1998); Frúgoli Jr. (2000); Nascimento (2006 e 2011); Medeiros (2006); Guasco (2001); Telles (2010); Pereira (2016); Feltran (2011) e Aderaldo (2017), entre muitas/os outras/os. Durante o percurso histórico compreendido entre a década de 1970 e os dias atuais, observamos ao menos quatro pontos fundamentais, conectados entre si, em torno das análises sobre esse lugar compósito chamado "periferia": espacialidade (1970), dinâmicas processuais (1970/1980), pluralidade/heterogeneidade (1980/1990) e representação (1990/2000). Em grande medida, tais pontos se interpenetram no avançar das décadas, produzindo análises que complexificam uma ou outra perspectiva de destaque, como as elencadas. É importante também apontar como a análise que parte de um ponto de vista etnográfico vai ganhando mais espaço, mesmo já presente desde os primeiros trabalhos acerca da "periferia". Se hoje há um cuidado maior em definir "periferia" e tensionar suas possibilidades conceituais, explicativas e/ou descritivas, isso se deve em grande medida ao esforço do trabalho de campo confrontado com ações dos próprios interlocutores ao

3 Embora a antropóloga Alba Zaluar tenha feito sua pesquisa de doutorado na favela Cidade de Deus, no Rio de Janeiro, a defesa da tese ocorreu na Universidade de São Paulo. Ademais, a confluência produtiva da autora entre São Paulo e Rio de Janeiro, através dos diálogos diretos com as professoras Eunice Durham (naquela ocasião sua orientadora) e Ruth Cardoso e com o professor José A. Guilhon, além de tantas/os outras/os, mostra o ganho acadêmico de seu trabalho a partir de contextos distintos de formação. Cientes de que "periferia" e favela não constituem conceituações análogas, sobretudo no que diz respeito às noções de "espoliação urbana" (Kowarick, 1979) e desigualdade social, contudo, não podemos deixar de notar que tais abordagens "consolidam a noção de 'padrão periférico de urbanização' enquanto modelo heurístico e, muitas vezes, como ideal-tipo. A segregação social das camadas populares de menor renda, a autoconstrução das moradias e a precariedade das condições de consumo coletivo são apontados como definidores desse "padrão periférico'" (Ribeiro; Lago, 1994:3). Não à toa, a tese de Zaluar continua sendo um clássico para as ciências sociais brasileiras. 
"Periferias" móveis: (homo)sexualidades, mobilidades e produção de diferença na cidade de São Paulo

protagonizar os discursos sobre seus locais de origem e suas vivências ${ }^{4}$.

Aspectos referentes à espacialidade e às dinâmicas processuais ajudam a localizar, portanto, o debate em torno do termo "periferia" através de uma chave analítica que inicialmente tratava este conceito como uma espécie de macroestrutura - um bloco homogêneo construído em oposição ao "centro". Um giro epistemológico na virada dos anos 1970 para os 1980 começa a reconhecer a necessidade de pesquisas voltadas à agência coletiva, com ênfase nos processos sociais, políticos (Caldeira, 1984) e culturais por meio da pluralidade de demandas - já que entram em cena movimentos expressivos de migração nordestina e nortista para São Paulo (Durham, 1978) e movimentos sociais urbanos de mulheres e de agentes comunitários (Viezzer, 1989; Telles, 1994; Correia, 2015).

A costura feita entre as noções de espacialidade e de dinâmicas processuais nos auxilia a compreender o componente histórico na ocupação da cidade. O manejo paulatino que foi vislumbrado e exercido nesse espaço urbano interpela os sentidos e significados diante do movimento migratório e imigratório que aqui se praticou. Do mesmo modo como reconhecemos a importância das migrações nordestina e nortista para a capital paulistana no período mencionado, não podemos deixar de notar o relevante fluxo imigratório, por exemplo, de japoneses (Cardoso, 1972) e italianos (Durham, 1966) nas décadas de 1920/1930 e 1940/1950, respectivamente. Tais mobilidades ajudaram a

4 Tais análises foram suscitadas durante o ciclo de palestras "Significado das periferias nas práticas e produções culturais: o olhar das pesquisas em ciências sociais", realizado no Centro de Pesquisa e Formação (CPF) do Serviço Social do Comércio (SESC) de São Paulo, no período de 7 de maio a 25 de junho de 2015. O ciclo foi organizado em parceria com os professores doutores Heitor Frúgoli Jr. e Jaime Santos Júnior, a quem agradecemos pela possibilidade de diálogo, bem como às/aos palestrantes Márcio Macedo, Érica Peçanha, Alexandre Barbosa, Guilhermo Aderaldo e Uvanderson da Silva. Estendemos nossos agradecimentos a todas/os as/os participantes do ciclo pela oportunidade de diálogo e debate. 
constituir, inicialmente, espécies de territórios identitários, assim como projetaram política, econômica, social e culturalmente certo reconhecimento estrutural $e$ imaginativo na dinâmica urbana a partir do contato entre brasileiros e estrangeiros e das lutas em torno de demandas de habitação, família, educação, segurança, trabalho, lazer etc.

A intensidade dos fluxos mencionados impactou diretamente as décadas posteriores. No decurso entre as décadas de 1980 e 1990, São Paulo presenciou um intenso processo de verticalização em sua paisagem urbana, sobretudo na delimitação mais fixa entre "centro" e "periferia", ocasionando níveis distintos de consolidação urbanística, o declínio da industrialização, a precarização do emprego e o aumento do mercado informal (Telles, 2010; Feltran, 2011).

Nesse sentido, as noções de pluralidade/heterogeneidade funcionaram como vetores de aproximação e distanciamento de grupos $e$ pessoas que passaram a se reconhecer como pertencentes à cidade, especificamente a bairros e zonas, além de produzirem processos de diferenciação marcados em espaços $e$ tempos específicos. O reflexo direto desse contexto refere-se aos avassaladores e desiguais movimentos de especulação imobiliária que expulsaram os setores mais precarizados da classe trabalhadora para áreas sem nenhum tipo de infraestrutura, criando, portanto, bolsões de pobreza e intensificando segregações e disputas socioespaciais, aspectos que remontam ao conceito de "heterogeneidade funcional" aventado por Caldeira (2000), sustentando os conflitos entre o aumento populacional $e$ as desenfreadas ocupações citadinas (leia-se: a construção de condomínios - "enclaves" - ladeados por favelas) pari passu às lutas por cidadania e pela democratização do acesso ao espaço urbano, levadas a cabo pelos movimentos negro e de mulheres moradoras/es, em sua maioria, de localidades "periféricas".

Por fim, na passagem dos anos 1990 para os anos 2000, em uma tentativa de adensamento de áreas mais "centrais", a noção de representação aparece com mais força como forma de qualificar a "periferia" enquanto lugar que se opõe ao "centro", 
especialmente pela representatividade negra e pobre-, mas também através de um conjunto de pesquisas que tematizam produções estético-culturais (Guasco, 2001; Nascimento, 2006; 2011; e Aderaldo, 2017), cultura e lazer (Magnani, 1998), juventude (Pereira, 2016) e sociabilidade lésbica (Medeiros, 2006). A possibilidade de olhar para a "periferia" do ponto de vista da representação, isto é, da expressão por excelência de um movimento de resistência, qualificou a relação binomial "centro" "periferia" / "periferia" - "centro" no sentido de superar possíveis isomorfismos entre pessoas e lugares e vice-versa. Na contramão de um olhar atávico, capaz de encerrar a cidade em si mesma, auto-explicativa em suas estruturas e relações, a observação do contexto atual nos mostra que os limites entre "centro" $e$ "periferia" são, cada vez mais, tênues e dependem dos pontos de referência destacados. Mais que isso, não se trata simplesmente de uma oposição geográfica, é antes uma estratégia representativa porque assume a responsabilidade de verbalizar demandas próprias, negociando com o que/quem chega, capitaneando novos/as atores e relações e direcionando o processo de circulação de bens, pessoas e grupos na cidade.

Levando em consideração o arco temporal apresentado, notamos possíveis aproximações entre ocupações citadinas, especificamente aos usos do espaço urbano, sociabilidades, sexualidades e um certo mercado consumidor. Na revisão de literatura na antropologia brasileira sobre sexualidade, sociabilidade e mercado desenvolvida por Facchini, França e Braz (2014), pelo menos três pontos nos chamam atenção: I (1960) - a presença, na produção acadêmica desse período, de uma acentuada noção de "gueto" articulada às vivências homossexuais pela via da clandestinidade; II (1980) - um notável processo de mudança social que demandou protagonismos específicos (de negros/as, de mulheres, de homossexuais) e localizados (nas "periferias", por exemplo); e III (anos 2000) - a elaboração de uma agenda política voltada para os "direitos sexuais", refletidas em legislações específicas para "grupos minoritários", nas Paradas do Orgulho LGBT, no considerável aumento de grupos de pesquisa 
em gênero $e$ sexualidade nas universidades brasileiras $e$ na constituição de "mercados" segmentados (espécies de nichos de consumo).

Se, a partir da década de 1960, a noção de "gueto" encontrava eco em uma série de pesquisas sobre homossexualidade nas ciências sociais em âmbitos internacionais e nacionais (Leznoff; Westley, 1998 [1956]; Achilles, 1992 [1964]; Warren, 1998 [1974]; Levine, 1979; Perlongher, 2008 [1987]; Macrae, 1983; Barbosa da Silva, 2005 [1960]; Guimarães, 2004 [1977]), não exatamente concentradas em estabelecimentos comerciais, mas também na constituição de redes (por meio de certa noção de "comunidade"), foi no processo de mudanças sociais, que se iniciou na década de 1980 e teve o seu ápice nos anos 2000, que uma maior expressão de "mercado" segmentado veio à tona (Cf. Facchini; França; Braz, 2014) $)^{5}$.

Cabe destacar que essa maior expressão de "mercado" segmentado inevitavelmente mostra direcionamentos para uma compreensão mais acurada da cidade. Basta termos em mente que se há uma expansão, por exemplo, de circuitos de lazer e sociabilidade em várias cidades brasileiras, em áreas "centrais" $e$ "periféricas", a própria noção de segmentação indica o quê $e$ quem deve ser atingido/privilegiado, ou seja, são aspectos evidenciados em marcações de espaço-tempo e, sobretudo, de classe social.

Portanto, mais do que tecer considerações a respeito da sociabilidade homossexual que se produziu/produz na cidade de São Paulo, pretendemos olhar de maneira crítica para as subjetividades que se constroem na circulação por espaços

5 Sobre os impactos e as transformações da homossexualidade em torno das noções de "gueto" e "mercado", ver o artigo de Júlio Simões e Isadora Lins França (2005). Ademais, o trabalho de Ernesto Meccia (2011) também indica caminhos para uma reflexão mais acurada sobre a homossexualidade contemporânea partindo de um contexto pós-ditatorial argentino. No contexto norte-americano, o trabalho de John D'Emilio (1993) serve como problematização acerca dos efeitos do capitalismo para a construção de uma identidade "gay". 
urbanos distintos e, nesta relação, compreender quais os efeitos $e$ rentabilidades do debate sobre marcadores sociais da diferença no âmbito dos discursos sobre "periferia"/"periférico", ser da "periferia", estar na "periferia". Assim, antes de destacarmos como se dá a relação entre sexualidade e "periferia", é mister destacarmos a feitura de uma cidade por meio de suas "geografias imaginativas" (Massey, 2013), ou seja, daquilo que é produzido por processos de legitimação cotidiana, circulação e significação contingente.

\section{Transitando entre "centro" e "periferia"}

Quando pensamos em espaço urbano e grandes cidades, em especial no contexto brasileiro, a separação entre "centro" $e$ "periferia" é constante. No caso de São Paulo é uma marca identitária geográfica a autoafirmação da pertença "periférica" em muitas manifestações culturais e políticas, em grande medida no sentido de reafirmar a falta, manifestada de forma muito diversa: falta de saneamento básico, de segurança, de escolas, de limpeza, de transporte, falta enfim de cidade. Em contrapartida, abundam relações entre violências e criminalidades, assim como manifestações e criações construídas como próprias à "periferia" como o rap, o funk e o grafite.

Neste sentido, quando falamos de espaço urbano, por exemplo, a adjetivação que conduz à espacialidade ou à urbanidade é também algo produzido socialmente; uma cidade existe enquanto tal a partir de como ela se torna produto das relações ensejadas em suas ruas, avenidas, bairros e conjuntos arquitetônicos. A separação, portanto, entre "centro" e "periferia" é parte dos discursos e ideais urbanos que fazem de São Paulo a cidade que toma forma ora como a "locomotiva do Brasil", ora

6 Nosso esforço neste texto é não o transformar em uma litania de marcações sociais. Como mostra Crapanzano (2001:447): "Talvez seja mais proveitoso começar de modo mais impessoal, com compromissos e confrontações interpretativas no intuito de determinar as condições pragmáticas por meio das quais essas próprias categorias são definidas e aplicadas". 
como "cidade global" 7 , dentre outras possibilidades classificatórias envoltas na ideia de progresso industrial $e$ financeiro.

$\mathrm{Na}$ esteira desse argumento, segue um rápido exemplo às margens da linha férrea urbana que liga os bairros da Luz e do Bom Retiro, no "centro" da capital, a cidades da região metropolitana, tendo como ponto final o município de Itapevi. No intervalo entre as estações Júlio Prestes e Barra Funda, na linha 8 da Companhia Paulista de Trens Metropolitanos (CPTM $)^{8}$, encontra-se a favela do Moinho, comunidade que data de meados dos anos 1990 e que recentemente tem sido alvo da ferrenha disputa do mercado imobiliário por terrenos na região "central".

Neste intervalo, nos vagões das extremidades das composições, há uma intensa troca sexual entre homens que se organizam em torno das possibilidades técnicas e significados que o trecho foi ganhando para tais atividades, contexto que será explorado adiante.

A favela se ergueu no espaço abandonado do moinho Matarazzo após o declínio da atividade industrial na cidade e se encontra hoje ao lado de uma das principais salas de concertos da América Latina, a Sala São Paulo, parte de um intenso processo de valorização do patrimônio arquitetônico da cidade e da tentativa de alteração do perfil social de transeuntes na região (Talhari; Silveira; Puccinelli, 2012). Esse processo, ainda em andamento, apresenta idiossincrasias, a exemplo das ações na chamada "cracolândia" (Frúgoli Jr., 2012), no bairro da Luz, que

7 Referimo-nos à expressão analítica cunhada pela socióloga Saskia Sassen (1993) em referência à relação do capital internacional entre um conjunto de municípios como uma marca mais forte do que uma identidade local, nacional ou regional. Inicialmente figuram nesse conjunto Londres, Nova Iorque e Tóquio, espectro ampliado a partir dos comentários críticos dessa formulação. Trabalhos recentes têm questionado os alcances explicativos, tomando São Paulo como campo de pesquisa (Ferreira et al, 2007).

8 A CPTM é uma empresa de economia mista vinculada ao Governo do Estado de São Paulo. Criada em 1992, a empresa substituiu as organizações estatais responsáveis pelos trens urbanos da região metropolitana de São Paulo e até hoje é classificada como de pior qualidade do que as linhas de metrô. 
evidenciam as disputas acerca desse espaço, distante das noções de "cidade global" ou "centro financeiro", comuns às definições dos "centros" da cidade, e bem mais próximo de "bolsões de pobreza" e crime, como costumam ser reconhecidas regiões periféricas e favelas: seriam estes "periferias" incrustadas no "centro"? Espécies de "periferias centrais/centros periféricos"?

Quando nos utilizamos de exemplos mais concretos de nossas pesquisas, podemos aventar mais claramente a forma diversa com que emergem significados variados de um mesmo contexto espacial. Temos, com isso, imaginações geográficas interpeladas por contextos gerais ou mais circunscritas por relações de poder e marcadores sociais da diferença, mas nunca plenamente fixadas. Por exemplo, esse trecho da via férrea entre as estações Júlio Prestes e Barra Funda ganha outros contornos de significação a quem o utiliza com fins de práticas sexuais, contexto mais restrito e menos conhecido dos movimentos sociais que têm se dedicado ao debate sobre moradia precária, pobreza e segregação espacial na cidade. Estão entrelaçadas hierarquias e diferenças que manejam desigualdades em termos de classe, sexualidade e raça e remontam às formas como "periferia" tem sido construída como um imaginário total também em relação aos usos sexuais dos vagões marcados por homens de classes populares e divisões acerca das performances de gênero que associam feminilidade, passividade e subalternidade. A "periferia" em movimento nos vagões segue, a princípio, poderia seguir o modelo hierárquico sugerido por Fry (1982) em seu ensaio clássico, mas as possibilidades de agência e mobilidade na produção de si entre as estações desvela a capacidade de fuga entre os sujeitos participantes desses enlaces sexuais furtivos (Perlongher, 2008 [1987]).

Tratar da "periferia" aqui corresponde a buscar na ideia contraposta à noção de "centro" suas possibilidades de análise crítica. Não vamos, certamente, tomar "periferia" como a distância quilometrada a partir do marco zero das cidades. Falamos, portanto, de uma contraposição, uma polaridade existente, pois é acionada e faz sentido na dinâmica social para além das teorias da 
cidade $e$ do espaço, mas que tem sido paulatinamente questionada na antropologia. Em especial, este questionamento advém dos próprios exemplos de campo, das etnografias e outras pesquisas realizadas com as pessoas alocadas no que se tem definido histórica e teoricamente como "periferia": moradores viventes nas franjas da cidade, nos limites produzidos ao longo da ocupação urbana orquestrada por conglomerados privados em conjunto com o poder público. Tais processos, que ajudaram a definir as fronteiras dos municípios, também reformulam as fronteiras entre o urbano $e$ o não-urbano, a civilização $e$ a precariedade, o lícito e o ilícito, o legal e o ilegal, o trabalho e o crime. Fronteiras estas em constante processo de reformulação, como apontam Caldeira (2000), Telles (2010) e Feltran (2011).

Se estamos focados nas contribuições supracitadas, em especial nas dinâmicas sociais, é fato que há determinados recortes sócio-demográficos que enfatizam a existência de uma "periferia", bem como de um "centro". No caso da primeira, bairros marcados pela moradia precária, autoconstruída, cujo acesso a direitos geralmente se faz pela iniciativa dos próprios moradores. Estes conformam grandemente o contingente negro $e$ migrante nordestino e nortista que fornece a mão de obra a empregos subalternizados ou a atividades ilícitas. Imagina-se, conforme o jargão coloquial, a "periferia" enquanto um lugar próprio para o desenvolvimento do crime, onde o "Estado ausente" intensifica a pobreza. E é distante do "centro"? Se considerarmos os diversos marcadores sociais de diferença acionados a partir de nossas experiências de pesquisa $e$ observação, teremos de repensar definições geográficas fixas e observar como as "centralidades" e "periferias", assim como o espaço e as pessoas que estão nele, operam e marcam diferenças. 
"Periferias" móveis: (homo)sexualidades, mobilidades e produção de diferença na cidade de São Paulo

\section{"Periferia" e (homo)sexualidades 9}

Se as geografias da cidade são imaginadas enquanto polaridades espaciais como "centro" e "periferia" é justamente porque os espaços são vividos e disputados por diferentes sujeitos, individuais ou coletivos, tensionando significados apriorísticos ou hegemônicos. Voltemos ao exemplo do trecho da via férrea, onde se localiza a favela do Moinho.

Por questões materiais e simbólicas, o trecho entre as estações de trem Barra Funda e Júlio Prestes, na linha férrea supracitada, cotidianamente é marcado pelo enlace sexual: no caminho da primeira à segunda, devido à diminuição da velocidade dos trens neste trecho, homens de idades, tipos físicos e performances de gênero diversos, cientes do tempo transcorrido até a chegada à estação, realizam trocas sexuais dentro dos vagões, que vão da masturbação à felação, muitas vezes com o término das atividades no sanitário público localizado na própria estação.

Fato de amplo conhecimento por instâncias organizativas da instituição de transporte, a dinâmica sexual milimetricamente organizada $^{10}$ apresenta uma outra possibilidade de leitura do espaço, em especial pela via do trânsito. É no trânsito dos vagões entre uma estação e outra que relações transitórias dão novo significado ao espaço restrito do trem e também ao espaço transcorrido. Neste, serve de paisagem lenta o muro da linha férrea e as casas de tapumes e lonas da favela do Moinho.

\footnotetext{
9 Pelos limites da argumentação, ater-nos-emos às contribuições dos trabalhos focados nas homossexualidades, cientes de que há um vasto campo de debate sobre as sexualidades de forma mais ampla. Para mais informações, ver a "Apresentação" de Piscitelli (2014) ao Dossiê "Antropologia, Gênero e Sexualidade no Brasil: balanço e perspectiva" nos Cadernos Pagu e a análise da produção de conhecimento sobre o tema feita por Facchini et alii (2013).

${ }^{10}$ Michael Pollak (1985) acentua como a repressão à prática sexual no espaço público, na década de 1970, mas ainda hoje, é um dos fatores que estimulam a criação de códigos, dissimulações e uma economia de aproveitamento máximo do momento das trocas sexuais entre homens.
} 
Poderíamos inferir, neste caso, sexualidades "periferizadas" visto que a prática sexual em lugares públicos, ainda que amplamente disseminada mundo afora, é das mais negativizadas no discurso público geral entre "gays", em especial no que tange à presença de sujeitos mais efeminados, negros e velhos.

Não à toa, os vagões preferencialmente ocupados por estes sujeitos estão localizados nas pontas, os primeiros e os últimos, perfazendo parte da dinâmica que os desloca dos "centros" (das composições dos trens, dos desejos hegemônicos) para as "periferias", aqui imaginadas em termos de análise espacial e a partir das relações de poder que deslocam sujeitos e sexualidade. Num jogo relacional entre o trem que se desloca pelo trecho favelizado e os espaços ocupados para as trocas sexuais, poderíamos aventar onde estaria uma possível "periferia", deslocada da relação perimetral metropolitana. Estamos falando de pobreza quando tratamos de "periferia"? Ou, ao que parece, o termo pode sugerir um jogo de deslocamento e/ou segregação a partir de determinadas hegemonias sociais, tais como uma performance de gênero homossexual mais viril, mais valorizada em relação a performances efeminadas. Jogamos, aqui, com os termos a fim de alcançar o jogo móvel disposto pelos sujeitos observados.

Este breve quadro que relaciona a favela $e$ as dinâmicas sexuais no transporte público permite vislumbrar diferentes possibilidades de conceituar "periferia". Por um lado, pela via mais comum da estrutura de classes que empurra para longe do "centro" a pobreza; por outro, pela via dos significados atribuídos ao que possa ser desejado, interessante e valorizado em contraposição ao negativizado.

Talvez repensar antigas fórmulas e elaborar novas perguntas seja um disparador da produção de problemáticas em torno de velhos e atuais modelos de explicação. A chave de explicação que propomos sobre tais compósitos requer cuidados que dizem respeito não somente à opacidade recorrente acerca de desigualdades e segmentações, mas sobretudo do que nem sempre foi preocupação da produção de conhecimento em 
décadas anteriores, como a sexualidade. Neste sentido, partindo das hierarquias e desigualdades desveladas pelo exemplo dos trens, no qual se cruzam desejos e deslocamentos entre estações, espaços "centrais" da cidade dentro dos próprios vagões, podemos partir de observações densas de atos muitas vezes secundarizados, como as trocas sexuais, para repensar a oposição "centro-periferia". Com isso jogamos luz numa relação produtora de subjetividades no plano do desejo sexual que se expande, inclusive, para a compreensão das desigualdades espaciais de uma metrópole.

Como mostra Caldeira (2000), tal oposição foi perdendo força ao longo desses anos e a expansão do olhar antropológico para a cidade, bem como da antropologia como disciplina (Magnani, 2012), respondem por parte desse processo. Enquanto esse sistema de compreensão não consegue dar conta da dinâmica urbana contemporânea - seja pela distribuição de renda, seja por novos padrões de organização social -, a mobilidade se apresenta como um dos componentes fundamentais para demonstrar quais "disposições de conhecimento e poder" (Chambers, 1995) estão, atualmente, em jogo.

Pensar que territórios ou espaços fixamente marcados na concretude das cidades podem se deslocar, ser lidos em termos de deslocamentos e trânsitos, enseja inúmeras possibilidades interpretativas da cidade. Aqui, pensamos em sexualidade $e$ partimos, por exemplo, da forma que Perlongher (2008 [1987]) cunha a expressão "territorialidades itinerantes" em sua obra a respeito da prostituição masculina no centro paulistano. Territorialidades itinerantes permitem discutir os deslocamentos não apenas dos sujeitos pelos espaços citadinos, por suas ruas, calçadas e esquinas, mas destes espaços entre e nos sujeitos que fazem parte do recorte da investigação. Falamos, portanto, de sujeitos e espaços significados e produzidos mutuamente, a partir de usos e movimentações. Através deste trabalho temos uma das primeiras abordagens da teoria antropológica sobre as cidades em consonância com sexualidade e homossexualidade, temas que paulatinamente ganharam esferas autônomas de produção no 
contexto brasileiro e internacional, mas que, no caso do primeiro contexto, estiveram em contato desde os anos 1980. Com o passar do tempo $e$ a institucionalização de grupos de pesquisa $e$ áreas temáticas nas pós-graduações, estudos urbanos e voltados a gênero e sexualidade obtiveram maior autonomia, aspectos apontados por Facchini et alii (2014). Mesmo seguindo com intensas trocas temáticas, tais áreas pouco têm investido no debate teórico fronteiriço entre si. De forma geral, ainda que essa afirmação suplante exemplos de congruência, são poucos os trabalhos que se dedicam a pensar espaços, sexualidades $e$ mobilidades como pontos de convergência teórica. Tal afirmação serve, neste artigo, como ponto valorativo das contribuições congruentes nas diferentes áreas temáticas.

Nosso desafio em aproximar debates sobre espaços, sexualidades, territórios, gênero, trânsitos, fronteiras, mobilidades toma como inspiração e referência, direta e indireta, um conjunto de autoras/es que têm se preocupado, de alguma forma, em descortinar experiências, narrativas e vivências atreladas intimamente a cenários urbanos marcados por consumos $e$ subjetividades (França, 2012), produções de diferenças $e$ afetividades (Facchini, 2008), mercados transnacionais do sexo $e$ do desejo (Piscitelli, 2013), sonoridades e estéticas (Marques, 2015), violências e territórios (Efrem Filho, 2017), prostituição feminina $e$ militância (Olivar, 2013), envelhecimentos e regimes de visibilidade (Passamani, 2015), espaço urbano e sexualidade (Puccinelli, 2017), "periferias" e mobilidades (Reis, 2016), entre outras/os. Em espaços e tempos distintos, cada uma/um das/os pesquisadoras/es citadas/os tonifica o debate em questão por meio do questionamento de determinados estatutos que tendem a tornar rígida $e$ fixa a maneira como são vividas, projetadas $e$ reproduzidas identificações e diferenciações.

$\mathrm{O}$ conjunto de pesquisas acima nos permite compreender o quanto as "territorialidades itinerantes" aventadas por Perlongher foram sintomáticas no processo de adensamento dos cruzamentos temáticos supracitados. O exercício de troca pelo qual está imbuída a pesquisa de Perlongher assevera que um dos requisitos 
"Periferias" móveis: (homo)sexualidades, mobilidades e produção de diferença na cidade de São Paulo

para o desenvolvimento de pesquisas em contextos urbanos com escalas distintas é a própria reflexão sobre o movimento ("trânsito"/itinerância), com vistas a interpelar, por exemplo, a produção de fronteiras, territórios/territorialidades, subjetividades e diferenças.

Retomando o trabalho de Perlongher, ele apresenta uma primeira ideia de trânsito entre "centro" e "periferia" pela via do desejo homossexual com relação aos deslocamentos de homens que se prostituem, comumente mais pobres, negros, jovens $e$ másculos. Estes michês se deslocam de seus lares e famílias, dos laços morais localizados em bairros distantes do "centro", para outro regime moral, que realoca corpos e desejos. Na região da República, "centro" paulistano, uma dinâmica específica produz deslocamentos e fixações e realoca "centralidades" e "periferias" que podem ser lidas a partir da sexualidade. De forma geral, $e$ resumida, é a partir deste ponto geograficamente localizado que as homossexualidades passam a fazer parte do escopo investigatório antropológico $^{11}$, especialmente a partir de concentrações de locais de encontro e sociabilidade, movimentos políticos e de defesa de direitos, moradia e incremento imobiliário: muitos são os temas que surgem recortando ou servindo de cenário a pesquisas diversas que pensam homossexualidades. E é nas regiões "centrais" de grandes ou pequenas cidades que tais roteiros parecem se desenrolar preferencialmente $e^{12}$.

Contudo, parece-nos promissor considerar tais contribuições a partir de alguns deslocamentos aqui propostos, como no

${ }^{11} \mathrm{E}$ importante ressaltar as abordagens originais que dialogam com as aproximações teóricas sobre o urbano presentes nas respectivas teses de doutoramento de Facchini (2008) e França (2012) e em Simões (2011). No caso das duas primeiras, o trânsito teórico ajuda a contestar certa fixação padronizada de identidades sexuais na cidade, além de representarem excelentes olhares sobre o lócus espacial privilegiado em nossa argumentação.

${ }^{12}$ Assim como em outros contextos nacionais, as pesquisas sobre homossexualidades partem e seguem para regiões "centrais" metropolitanas. Se isso está relacionado com uma ocupação citadina mais visível, também aponta recortes vindos da própria produção acadêmica sobre o tema. 
exemplo das trocas sexuais nos trens. Tomar as regióes de concentração de lugares de encontro como marcos para a observação e análise das "sexualidades dissidentes" pode apenas inferir um vetor de deslocamento, da "periferia" ao "centro", reafirmando o contingente frenético das grandes cidades como lugar do anonimato $e$, por isso, espaço preferencial para expressão daquilo que pode ser condenado socialmente. Ora, tal concepção ignora que, mesmo num contexto mais amplo de "cidadanização da homossexualidade" (Carrara, 2016), com conquistas jurídicas e aumento de uma visibilidade positiva, há práticas sexuais que seguem sendo marginalizadas, ou, em termos interessantes para pensar o lugar da sexualidade na análise citadina, "periferizadas". Dessa forma, podemos olhar as trocas sexuais nos trens como formas expressivas de realização de uma sexualidade "periferizada" a partir de sujeitos que também podem estar alocados em lócus desejantes marginais e desvalorizados e se utilizam do trânsito contínuo como forma de fuga expressa tanto na repressão social quando na normatização identitária, conforme aponta Perlongher (2008 [1987]). O desígnio de um espaço na cidade, próprio e definido para a realização de expressões da homossexualidade, escapa nos interstícios dos trânsitos mobilizados por desejo e repulsa, ainda que os mesmos sujeitos circulem também pelos espaços "centrais" mais normatizados, conforme citado. Afinal, as identidades são produzidas nos contextos em que as relações sociais se dão (Brah, 2006) ${ }^{13}$.

\footnotetext{
${ }^{13} \mathrm{Na}$ dissertação de mestrado de Puccinelli (2013), realizada em um shopping de São Paulo frequentado por "gays", há uma interessante correlação entre a separação de áreas próprias de presença de homens mais velhos e mais gordos, os "ursos", e áreas com maior frequência de homens mais jovens e musculosos, as "barbies", que renegam as trocas sexuais das quais também fazem parte nos banheiros masculinos, operando em três divisões que se cruzam a todo momento.
} 


\section{Deslocamentos polifônicos: despolarizando "centro" e "periferia"}

Como já dito, a região da República, no "centro" da cidade, é historicamente marcada pela ocupação e pelo trânsito de diferentes expressões de homossexualidade. Parte das investigações tratadas neste item têm se detido nessa espacialidade tanto por ser um ponto recorrente de referência à temática quanto pelo trânsito com diferentes interlocutores da pesquisa. Dessa forma, duas perspectivas se cruzam no relato que segue: a fixação e o deslocamento.

Numa tarde de domingo de dezembro de 2014, indo de metrô ${ }^{14}$ à Praça da República, na região "central" de São Paulo, encontramos um interlocutor de pesquisa caminhando para a saída da Rua do Arouche. Apressamos o passo para alcançá-lo e iniciar uma conversa. Diego ${ }^{15}$ fez parte de pesquisa de campo realizada durante o caminho percorrido para a realização de uma reunião de militantes LGBT (lésbicas, gays, bissexuais, travestis e transexuais) na "periferia", no bairro do Grajaú, extremo sul de São Paulo, cerca de quatro meses antes deste encontro. Curiosamente, o grupo se reuniu para esse trajeto numa estação de trem mais próxima à "região central" de forma a permitir o encontro de um maior número de pessoas para, então, seguira ao Grajaú, mesmo a maioria dos presentes morando na região sul.

No encontro do domingo, Diego aparentava se deslocar ao Largo do Arouche para encontrar seus amigos e se juntar ao enorme contingente comum nestes dias da semana, chegando a centenas de pessoas. Em 1987, Perlongher mostrava o Arouche como a "boca do luxo" dentro do "gueto gay" paulistano em contraposição à "boca do lixo", separadas pela Avenida São João. O largo teria a presença de moradores e frequentadores mais instruídos e de classes mais abastadas, além da oferta de restaurantes e bares mais sofisticados, enquanto a outra "boca",

\footnotetext{
${ }^{14}$ Transporte público sobre trilhos com parte de sua malha subterrânea.

${ }^{15}$ Por uma questão ética, os nomes de todos os interlocutores citados neste texto são fictícios.
} 
símbolo da cinematografia marginal paulistana, seria marcada pelo trânsito do crime e da prostituição. O passar dos anos parece demonstrar uma constante ingurgitação de boca a boca e, hoje, o que teria se firmado como uma extensão do lixo volta a ser produzido como luxo ${ }^{16}$.

A avaliação de Diego não destoava muito das duas concepções. Ao ser perguntado sobre as vindas dele e dos amigos ao largo todos os domingos, seu semblante mudou para algo contrariado e assertivo: "Eu não gosto da Vieira ${ }^{17}$, eu não gosto daqui. Hoje vou vir pela última vez só para resolver uma briga que eu tive com outro cara e não pretendo mais voltar". Diego afirmou já ter vindo muito ao largo, desde que era mais novo, mas diz não se sentir mais à vontade por conta do consumo de drogas como álcool, cigarro e maconha e do ambiente de "pegação". Disse hoje se sentir mais maduro e mais tranquilo em casa ou na praça da esquina, em seu bairro de moradia, onde encontra amigos da escola e do bairro. É curioso alocar esse discurso ao fato de Diego ter, à época, 18 anos de idade e afirmar se deslocar ao Arouche desde os 14 anos, denotando uma frequência predominantemente jovem.

Essa afirmação de Diego é interessante e remonta a outros contextos de pesquisa em espaços de encontro e sociabilidade frequentados por e definidos amplamente como "gays". Num destes casos, ao questionar o porquê de alguns homens irem com frequência ao Shopping Frei Caneca ${ }^{18}$, por exemplo, muitos deles afirmavam motivos utilitários ou objetivos, como ir ao cinema $e$ ao supermercado e logo voltarem às suas residências. A observação

\footnotetext{
${ }^{16}$ Parte da pesquisa de Puccinelli (2017) tem focado no crescente interesse do mercado imobiliário residencial que se aproveita tanto da presença homossexual quanto da remota lembrança do Arouche como espaço de sofisticação para intensificar seus investimentos.

${ }^{17}$ Termo êmico para se referir ao largo. A referência é a Avenida Vieira de Carvalho, um dos acessos ao Arouche.

18 Inaugurado em 2001, o shopping ganhou repercussão em 2003, após a expulsão de um casal gay que trocava beijos em seu interior, provocando mobilização para uma manifestação pública contrária à ação do shopping.
} 
contínua da pesquisa permitiu contrapor tais discursos, que se assemelham ao de Diego, já que estes mesmos interlocutores faziam parte do público assíduo às trocas sexuais nos sanitários, impelindo o shopping a tentar estratégias para coibir tais práticas. Intrigava antes mais a produção negativa do espaço como um lugar identitariamente gay, já que a menção à homossexualidade recaía sobre a atividade sexual pública, do que a percepção de contradições entre discurso e prática.

Uma sugestão interpretativa pode advir da conversa com Eliel, que se autoidentifica como "pardo" e reside com os pais no Jardim Miriam, também na região sul. Amigo de Diego, tem 27 anos e afirma ser um "jovem gay da periferia" ou "jovem LGBT da periferia". Mesmo utilizando o termo "gay" como forma de se identificar, ele prefere reforçar seus locais de "origem" ao falar de si: uma região distante do "centro" e a militância LGBT. Bastante articulado com as políticas municipais que envolvem pessoas LGBT, Eliel mostra em seus trânsitos como a cidade se caracteriza em termos de sexualidade legitimada.

Assim como Diego, quase em todos os domingos, Eliel está com o namorado e um grupo de amigos no Largo do Arouche. Há, pelo menos, outros três lugares que estão dentro de um circuito de preferências no trânsito de Eliel e seus amigos: o Parque do Ibirapuera (zona sul), uma praça no Tatuapé (zona leste) e a "Augusta" (referência à Rua Peixoto Gomide no trecho que liga as Ruas Augusta e Frei Caneca). É interessante considerar este último lugar, a "Augusta", como parte das preferências de Eliel, principalmente utilizada nas madrugadas de sexta-feira $e$ sábado.

As ruas, dias e períodos de ocupação são pontuais $e$ determinam maior ou menor apreço pelo espaço. A "Augusta" de Eliel não é boa como a "Vieira". Conversamos num domingo, sentados no largo do Arouche, enquanto as centenas de pessoas circulavam, conversavam e vinham tratar com Eliel:

Eliel: "Tem um monte de gente que vai na 'Augusta', se droga e fala mal da 'Vieira', mas também vai na 'Vieira'. 
Um monte que acha que estar na Augusta é ser superior. Lá só tem drogado, 'A Lôca' é famosa porque só tem drogas". $\mathrm{Na}$ 'Augusta' só tem playboy, bicha rica, metida. Se alguém peida lá, enche de polícia para mandar a gente embora. Aqui até tentam, mas não conseguem. É o lugar no centro ocupado pela população jovem LGBT de periferia. Prefeitura, Estado preferiam que a gente nunca saísse da periferia. Eles querem negros, afeminados e pobres longe do centro. Então a gente vem aqui e resiste, vem e ocupa $e$ irrita essas pessoas. Mesmo na 'Augusta', a gente incomoda".

A ênfase de Eliel, neste caso, refere-se à discriminação da área do entorno da "República" pelas pessoas que circulam pela "Augusta". Isso acontece a partir de apontamentos de interlocutores que reconhecem na área da "Augusta" um espaço de maior liberdade e com presença de iguais, ou seja, com a ausência do que reconhecem como aquelas pessoas que comumente vão à "República". Isso é importante porque, num primeiro olhar, reforça a ideia de duas espacialidades de presença homossexual distintas, com recorte de classe mais evidente (na "República" haveria a presença de estratos mais pobres, o que a tornaria menos interessante para os interlocutores frequentadores da "Augusta").

Contudo, como observa Eliel, as pessoas circulam entre as duas regiões com diferentes interesses e desejos. Os lugares ocupados na "Augusta" teriam o poder de tornar alguém superior pela simples presença, incluindo aí uma superioridade masculina dentre performances subjetivas e a avaliação de outras pessoas como desejáveis afetivo-sexualmente. Isso é relativo também à forma como seus próprios pares atuariam em relação a si $e$ outrem, com maior valoração enquanto parte da "Augusta", a região que masculiniza. Como meio de se diferenciar ao produzir alteridades em termos de espaço, gênero, sexualidade e classe, principalmente, Eliel se coloca de forma crítica a esse processo de depreciação da "República", mas pouco consegue escapar à dinâmica mais geral e ampla de trânsitos e diferenciações: o que 
"Periferias" móveis: (homo)sexualidades, mobilidades e produção de diferença na cidade de São Paulo

pareceria ser um só "centro" se desdobra em espaços diferentemente ocupados por pessoas da "periferia" $e$ "periferizados" de diferentes maneiras ${ }^{19}$. Existe, sobretudo, uma construção de narrativas ambivalentes sobre cidade.

Estamos lidando com diferentes regimes espaciais que se interpenetram. De longe, "Vieira" e "Augusta" conformam uma mesma centralidade de trânsitos homossexuais; numa leve aproximação, podemos aventar tratarem-se antes de espacialidades diferentes, com fronteiras mais ou menos perceptíveis e sentidos antagônicos; mais de perto, contudo, a circulação impõe uma análise que se detenha nos diversos fluxos espaciais, sexuais e semânticos que mobilizam os sentidos das dinâmicas observadas e acompanhadas. Temos aqui tanto a imagem consagrada do antropólogo que se desloca quanto o próprio deslocamento dos interlocutores como instâncias necessárias à compreensão dos deslocamentos significantes entre "centros" e "periferias".

\section{Movimento-ação: a mobilidade como produtora de sentido}

"A cidade não se relaciona com a periferia". Esta frase foi dita em uma das conversas com um interlocutor, Tarcísio, que frequenta o bar Guinga's ${ }^{20}$, em julho de 2013, em São Mateus, na "periferia" de São Paulo. Tarcísio prosseguiu:

${ }^{19}$ Concernente ao viés transformativo pelo qual passou a região do "centro antigo" de São Paulo, o que inclui o Largo do Arouche e suas imediações, Heitor Frúgoli Jr. aponta: "[...] o centro tradicional paulistano, que no início do século fora um espaço das elites, passou por um crescimento com a criação de áreas mais valorizadas, ao passo que as anteriores foram sendo gradativamente abandonadas e entregues à deterioração de seus equipamentos. A partir de então, o centro tradicional passou a ser cada vez mais identificado como espaço das classes populares [...]" (Frúgoli Jr, 2000:38).

${ }^{20}$ Localizado na avenida Sapopemba, 13.780, o bar Guinga's existe desde 2005 e ganhou ampla notoriedade após ter vencido na categoria "Casa de Show LGBT" durante a $3^{a}$ edição do Prêmio Papo Mix da Diversidade em 2014. Mas desde 2013, com o lançamento do projeto "Tô Ke Tô, o bar começou a ser amplamente reconhecido na "noite gay" paulistana pela presença de várias drag 
O centro não se relaciona com a periferia. Tanto que você percebe a questão do vestuário, da linguagem, a musicalidade, tudo isso se diferencia de quando você está numa balada de uma região central para uma região periférica.

Esse trecho ressalta a questão da circulação, não apenas por conta da suposta invisibilidade da "periferia" para o "centro", organizada numa chave interpretativa da sociabilidade homossexual como algo interditado nas áreas distantes do "centro", mas principalmente porque essa invisibilidade (a partir das especificações da fala de Tarcísio) não está alheia a um contexto mais amplo, do qual se notam conexões e distinções de estilo, linguagem, corporalidade, diferença, relação, "centros", "periferias".

Nesta seção, procuraremos nos deter em torno do argumento da circulação a partir de uma política relacional/de conectividade (Massey, 2013; 2000), ou de uma política que envolve movimento material, significado e prática móvel (Cresswell, 2009), que perscruta os efeitos e os sentidos das movimentações (ou dos movimento-ações), de jovens homossexuais, também chamados de "bichas" (majoritariamente negros), moradores de determinadas "periferias" da cidade de São Paulo. Seguindo essa pista, corroboramos com a perspectiva espaço-temporal presente em Massey, na qual a noção de espaço é uma produção aberta e contínua sempre construída em relação a algo/alguém.

Tal proposição interpela a constituição de políticas de mobilidade e de acesso, ou seja, de políticas de circulação que enfatizam os lugares enquanto processos. Por conseguinte,

não é possível entender o 'centro da cidade' - por exemplo, a perda de empregos ou o declínio do trabalho de

queens famosas. Ademais, a inclusão do nome do bar no Guia Gay de São Paulo, em 2015, situou o espaço nas opções de sociabilidade homossexual produzidas na "periferia" de São Paulo. 
manufatura que lá ocorre - somente pela observação do centro (Massey, 2000:184).

$\mathrm{O}$ ato de circular e o efeito da circulação se aproximam de um movimento-ação, onde o ir e vir, que cruza malhas urbanas, abrange de maneira significativa pessoas e espaços, em um exercício de dar sentido ao trajeto percorrido.

Esse movimento-ação - neologismo inspirado diretamente em Massey (2013) - corresponde a uma problematização do paradigma da mobilidade na produção de relações sociais que não se bastam apenas pelo efeito de ir e vir. Trata-se, sobretudo, da construção de cartografias situacionais (re-criações individuais e coletivas, isto é, movimentos compósitos produtores de sentidos e significados múltiplos) que, no caso desta etnografia, destoam das marcações mais constantes nos trabalhos que tratam sobre espaço de lazer e divertimento de "gays" e por isso re-criam pontos de chegada, estada e saída. Ademais, o movimento-ação é um contraponto analítico para narrativas e imagéticas legitimadas por escalas geográficas hierárquicas, ou seja, que atualizam a posição de necessidade das regiões "centrais" das grandes metrópoles como o lugar da fruição homossexual em contraponto a uma "periferia" retrógrada, atrasada e discriminatória. Coadunase, por exemplo, aos apontamentos críticos da naturalização da diferença sexual em Butler (2010) e da sugestão do espaço como algo dado em Massey (2013) na reafirmação cotidiana dessas definições. Aqui olhamos para espaços e sujeitos recriados nas relações materiais e simbólicas atualizadas em suas circulações.

Circular, portanto, não é compreendido apenas como objeto de troca, pois pode ser percebido também como uma apropriação interseccional que possibilita olhar para expressões de gênero, sexualidades, classes, cores, idades, gerações, desejos, intenções, vontades, transformações espaço-temporais, algo que não está restrito ao movimento de saída da "periferia" para o "centro" (Magalhães, 2008). Desta feita, nossos esforços em refletir sobre a mobilidade, tendo em vista certa dificuldade em definirmos um termo de análise (trânsito, deslocamento, circulação, fluxo, 
contrafluxo), dispõem-se sobre três elementos mais amplos subjacentes à própria noção de mobilidade, tal como propõe Cresswell (2009):

\begin{abstract}
A mobilidade é um emaranhado de movimento físico, de significado e de prática. Cada um destes elementos da mobilidade é, em meu entender, político. Mobilidade é também movimento social. Combina o movimento (de pessoas, de coisas, de ideias) com os significados $e$ as narrativas que os circundam. Permite igualmente reconhecer o facto de as mobilidades serem produzidas dentro dos sistemas sociais que, por sua vez, ajudam a configurar. As mobilidades não podem ser compreendidas sem reconhecermos que existem em inter-relação e em relação com várias formas de fixidez (Cresswell, 2009:25, grifos nossos).
\end{abstract}

Se Cresswell pensa em aspectos materiais, nos significados e nas práticas referentes ao movimento, é exatamente para trazer à tona questionamentos necessários para essa discussão, quais sejam: Como a mobilidade é constituída discursivamente? Que narrativas têm sido construídas sobre a mobilidade? Como as mobilidades são representadas? São questões que dizem respeito diretamente aos seis temas aventados pelo autor na produção das mobilidades: força, velocidade, ritmo, caminho, sensação/experiência e fricção.

Embora Perlongher não tenha construído uma análise específica sobre a mobilidade, ao cotejarmos o argumento acima com a análise dos trânsitos de seus interlocutores, podemos localizar exercícios de movimento que traçam um diálogo entre cidade e desejabilidade; as noções de "sujo", "lixo" e "luxo" marcam socialmente quem faz parte dessa dinâmica, onde ela está localizada, quando e como aparecem. Nesse sentido, o trânsito sexual analisado pelo autor ganha sentido por meio de uma chave que tanto se coloca em relação ao binômio "centro-periferia" quanto permite ponderar que as noções de decadente e desejável, 
por exemplo, fazem parte de um sistema de explicação que ultrapassa a imaginação simplista sobre o movimento.

A partir de nossas incursões, notamos que tal perspectiva relacional se constitui também em conexão com regiões "centrais" de São Paulo, a despeito da existência de sociabilidades que se constituem em função do local de moradia. Durante as idas ao bar Guinga's, conhecemos Oton, um rapaz de 34 anos, que se autoidentifica como "homossexual". O primeiro contato com ele ocorreu durante uma de suas apresentações no karaokê do bar. Ele, simpático e sorridente, chamava atenção pela extensão vocal e por certa semelhança com o timbre da cantora Alcione. Quase sempre, a pedido da plateia, ele cantava alguma música desta cantora $e$, ao término de sua apresentação, costumava ser ovacionado.

No período em que conhecemos Oton, no primeiro semestre de 2013, ele trabalhava em uma loja no shopping Aricanduva (zona leste). De uma família de origem nordestina, ele se reconhece enquanto "negro" $e$ "pobre", marcações sociais que ele agencia com veemência e orgulho. Com o tempo, notamos que ele era um frequentador assíduo do bar. Em uma de nossas conversas, nós o questionamos sobre tal frequência:

Pesquisador: Você poderia comentar por que frequenta o Guinga's?

Oton: "[...] Em uma das conversas com um amigo, eu falei assim: 'Ah, eu vou no Guinga's porque eu canto, eu converso com todo mundo'. Ele disse: 'Credo! Aquilo é lugar pra pessoas de boa índole ir?'. Aí eu falei assim: 'Ué, mas você mora na zona leste!'. [O amigo retrucou]: 'Ah, mas eu não sou igual a esse povo.' Eu falei assim: 'Como não?! Você é pobre, tão pobre quanto eles e quanto eu. Você não é melhor e nem pior do que nenhum que está ali dentro!' Então eu descarto. Eu gosto de vir aqui no Guinga's porque está perto da minha casa, eu canto, eu danço se eu quiser; e se eu tiver de saco cheio, eu vou 
embora, se não tem ônibus, eu vou a pé. Ah! Fico nervoso!".

Nesse trecho são descortinados desmembramentos sobre os modos como Oton dá sentido aos seus movimento-ações. Notamos que existem fluxos (da "periferia" para o "centro") que ocorrem por questões de classe social e de certa ausência de entretenimento na "periferia", bem como contrafluxos (do "centro" para a "periferia") e circulações (por "periferias"), seja para dar visibilidade a determinadas sociabilidades e espaços, seja pela facilidade de locomoção (no caso das pessoas que moram no bairro, a exemplo de Oton). Parte dessa circulação endógena é vista por uma chave acusatória a partir de quem está no "centro" e procura se distanciar da "periferia", ou por quem mora na "periferia" e nega a possibilidade de ser reconhecido enquanto morador de "periferia". O termo êmico "bichinha de bairro" é constantemente acionado nessa dinâmica, algo que nos faz lembrar automaticamente da categoria êmica "bicha popular" (rude, espalhafatosa, feia) presente na pesquisa de Isadora Lins França (2012:250) ${ }^{21}$ em contextos de "periferia" na cidade de São Paulo. Tal processo de trânsitos acusatórios sobre homossexualidades indesejadas e que reforçam a polaridade entre "centros" e "periferias" se aproxima do exposto por Eliel na relação entre a "Vieira" e a "Augusta". De seu ponto de vista, a primeira é desvalorizada por quem está na segunda, algo reforçado por interlocutores assíduos à "Augusta" quando se

\footnotetext{
${ }^{21}$ Segundo França, essa categoria êmica foi visualizada com mais clareza na sua etnografia realizada em um samba gay - o Boteco do Caê - localizado na Rua Bento Freitas, área contígua ao Largo do Arouche, Praça da República e Avenida Vieira de Carvalho. Em seus termos: "No samba também foi possível visualizar com maior clareza a figura da bicha popular, posição evitada por boa parte dos homens que acessei durante a pesquisa - e que parece assombrar a todos com a ameaça da vergonha e da abjeção social. Encontrei ali uma versão da bicha cujas histórias realmente passavam, em certa medida, pela vergonha e pela abjeção, mas que não se resumiam a isso, falando também de um lugar que, em relação aos seus pares héteros ou aos que não bichavam, trazia vantagens sociais $e$ permitia maior mobilidade - geográfica e social" (2012:250).
} 
"Periferias" móveis: (homo)sexualidades, mobilidades e produção de diferença na cidade de São Paulo

referem à outra região como lugar de gente "cagadinha", "feia", "suja", "escandalosa", "doente"22.

Em outra situação de campo, na festa Plasticine no bar Luar Rock $^{23}$, em Itaquera (zona leste), conhecemos Sérgio. De 26 anos, morador de Guaianases (extremo da zona leste), ele se identifica como "homossexual" e "branco". Parte da família é de origem nordestina, pertencente a estratos populares. Sérgio divide seu tempo entre o trabalho de DJ na festa Plasticine, onde também é promoter, além de discotecar em festas na Rua Augusta e imediações, bem como em cidades da região metropolitana de São Paulo, como Mogi das Cruzes, além de trabalhar durante o dia em um salão de cabeleireiro na Rua Augusta.

Durante uma de nossas conversas, na festa Plasticine, perguntamos a ele quais os lugares que costuma frequentar em São Paulo:

Sérgio: "[...] O meu bairro [Guaianases] não tem nada. Então, geralmente, quando eu vou fazer alguma coisa, ou tem que ser no outro bairro, que é em Itaquera, que tem shopping, tem tudo! Para lazer, eu gosto de ir, mesmo, para a Augusta, Liberdade, ou para Mogi [das Cruzes] geralmente para as baladas. Mas eu gosto, mesmo, das coisas da Augusta... É São Paulo, tipo, é o centro, aqui [Augusta e proximidades] é o centro de São Paulo, é o centro de tudo!".

\footnotetext{
22 Tais termos referem-se especificamente às conversas com Adriano, 27 anos, autoidentificado como "branco" e frequentador da Rua Frei Caneca.

${ }^{23} \mathrm{O}$ bar existe desde 2001 e está localizado na rua Carolina Fonseca, 35, Vila Santana, SP. A estrutura do espaço está disposta por meio de diversos ambientes com paredes deterioradas, pixadas e pintadas de preto, além da pouca luz, assemelhando-se a um porão, algo que corresponde a própria história do bar e da predominância de um estilo musical denominado por muitos como "rock de garagem". Identificada enquanto um evento "underground alternativo" pelo organizador (Sérgio), a festa reúne majoritariamente jovens heterossexuais e homossexuais advindos de "centros" e "periferias" da cidade de São Paulo, cuja finalidade é torná-la múltipla em gêneros musicais; nesse sentido o apelo pop, por vezes, garante o tom da festa.
} 
É interessante notar a configuração de circuitos de lazer $e$ sociabilidade além daqueles considerados mainstream nos movimento-ações de Sérgio: morador de Guaianases (zona leste de São Paulo), consumidor de um shopping em Itaquera (zona leste de São Paulo), frequentador das "baladas" da rua Augusta (epicentro de sociabilidade homossexual e heterossexual em São Paulo), frequentador da sociabilidade na Liberdade (bairro tradicionalmente conhecido pela imigração japonesa), contíguo aos bairros da região do "centro antigo" de São Paulo, frequentador de Mogi das Cruzes (região metropolitana da capital paulista) por trabalhar como DJ em uma festa nessa cidade. A cartografia situacional de Sérgio, isto é, os manejos feitos por ele em torno da relação entre equipamentos urbanos, mobilidades $e$ sociabilidades, funciona como vetor de direcionamento para marcar socioespacialidades; o desenho do movimento-ação de Sérgio, portanto, desvela seus usos do espaço urbano na esteira do que ele constrói como referência, representação e apropriação da cidade.

Oton e Sérgio perscrutam a cidade de maneira particular. Seus movimento-ações atravessam "centros" $e$ "periferias" (re)criando estratégias de apropriação do espaço urbano. Não obstante haver sinalizações que envolvem a constituição de representações estruturais baseadas numa noção cartográfica, vale lembrar que a maneira como eles agenciam seus movimentos está relacionada com a produção de cartografias situacionais

que buscam desorientar, desfamiliarizar, além de expor as incoerências e fragmentações do próprio espacial (nesse caso, primeiramente, o espaço da cidade) (Massey, 2013:162).

Se mapas são, sobretudo, representações ou arquétipos de representação, que há muito tempo compreendem um esforço em subjugar o espacial, faz-se necessário olhar tanto para mapas quanto para espaços enquanto abertos e em constante curso. 
"Periferias" móveis: (homo)sexualidades, mobilidades e produção de diferença na cidade de São Paulo

Puccinelli (2015:117) é enfático em afirmar que se, por um lado, são legitimadas cartografias de poder que "constroem uma ideia de centro que se desloca em relação ao que seria o centro oficial da cidade, tornando-o, portanto, mais desejável, por outro produzem uma rede de sexualidade desejável traçada nos mapas desse centro". Esse modo de construir acessos e desejos serve de mote para amparar os significados de "decadência" $e$ "revitalização" de áreas consideradas inóspitas e inabitáveis por conta, por exemplo, da frequência de moradoras/es de regiões "periféricas". Esse movimento-ação, considerado por Reis (2017) como "periferização central", é exatamente o que tensiona a necessidade de olhar para territorialidades como marcadores sociais e estimular reflexões comprometidas com o espaço urbano e suas fissuras. Conforme assevera Iain Chambers (1995):

Los fluctuantes contextos de lenguajes y deseos atraviesan la lógica de la cartografia y exceden las fronteras de su espacio tabular, taxonómico. Más allá de los bordes del mapa entramos en las localidades del mundo vibrante, cotidiano $y$ en una perturbadora complejidad. Nos encontramos aquí con la ciudad marcada por el género, la ciudad de las etnicidades, de los territorios pertenecientes a diferentes grupos sociales, con centros y periferias en desplazamiento, con la ciudad como un objeto determinado de diseño (arquitectura, comercio, planeamiento urbano, administración estatal) que simultáneamente resulta plástico y mutable: un lugar de acontecimientos, movimientos, memorias transitorios. Se trata por lo tanto, también, de un espacio significativo para analizar, para pensar $y$ compreender críticamente (Chambers, 1995:128).

Concluindo, torna-se evidente que os meandros que nos levam aos significados de pertencimento/distanciamento, fluxos/contrafluxos, identificações/diferenciações e distância/ proximidade dão conta do que está entre a abertura e o fechamento de tais circuitos, ou seja, do que está/pode estar solto pelo caminho. Nos pontos de chegada e partida existe o que 
podemos chamar de entre-lugar, algo que nem sempre é dito ou percebido. É onde acionamos (nós - pesquisadores - e os interlocutores) nossas limitações, temores, leituras $e$ comprometimentos, aspectos que representam sentidos e efeitos de cada circulação. Nesse sentido, os exercícios de mobilidade que são construídos resultam de movimentações distintas porque subscrevem ambivalências, por exemplo, entre ser morador de "periferia" e não usufruir de seus equipamentos de lazer $e$ sociabilidade; afirmar-se enquanto morador de "periferia" e se apropriar dos serviços locais; ou não ser morador de "periferia" $e$ se valer dos espaços e das sociabilidades produzidas nesses lugares.

Desta feita, com o decorrer das entrevistas e conversas, tais (des)centralidades e mobilidades ganham fôlego porque, direta ou indiretamente, as falas e vivências construíram caminhos $e$ representações distintas da cidade. Como dito, a polaridade binária faz sentido porque é amplamente utilizada em campo: Eliel se define em termos de sujeito "periférico", Tarcísio afirma que a "cidade não se relaciona com a periferia" e tais expressões não podem ser deixadas de lado. Contudo, é necessário atentar para as formas pelas quais estas identificações ganham força e sentido nos trânsitos. A afirmação de Eliel ocorre no espaço "central" do Arouche também em relação à "Augusta"; já Tarcísio maneja sua valorização na própria ocupação do que ele entende como "periferia". Observamos, portanto, regimes de espacialidade diferentes, "periferizações" diferentes, as quais ganham corpo ao aventarmos os diferentes marcadores de diferença trabalhados em intersecção: raça/cor, classe social, status, estilo, corporalidade, espaço agem contingencialmente nas falas, identificações $e$ localizações de si e de outrem. Quando nos referimos a "periferias" móveis, não se trata de uma reificação da noção de mobilidade, mas num deslocamento do olhar focado no espaço quilometrado que parcialmente dá conta dos sentidos de "periferia" para um olhar nos sentidos dos interlocutores e na análise situacional. Se há "periferia", o singular que define limites 
mais estáticos pode ser pluralizado e deslocado para o "centro". As "periferias" se movem.

Portanto, propor escritas e vivências citadinas entre aspas $e$ móveis significa dizer que estas são residuais no sentido de não encerrarem completudes geográficas e espaciais. Os processos de urbanização na capital paulistana mostram não somente que "centro" e "periferia" são passíveis de distintas e diversas transformações espaço-temporais, assim como as leituras e os comprometimentos das pessoas com esses lugares definem as formas que cada uma/um acessa e deseja a cidade. É a partir da pesquisa de campo e do olhar detido que podemos co-produzir significações diversas sobre polaridades cujas implicações de diferenciação em termos de "centro" e "periferia" são recortadas por relações de poder, discriminação e segregação, mas também a partir da emergência de sentimentos de pertencimento $e$ semelhança.

Se, por um lado, certos lugares no "centro" são desvalorizados e "periferizados" em relação a outros, como ocorre com a República em diversas situações em que termos depreciativos são utilizados para descrever as pessoas que lá se encontram ("cagadinhas", "doentes"), por outro lado, mesmo a ida a lugares localizados em bairros da "periferia" pode ser também questionada e desvalorizada, como no caso em que Oton é interpelado por seu amigo. Contudo, se nos ativermos apenas a estes exemplos, reproduziremos discursos mais amplos de exclusão "periférica" em termos de classe e perderemos a dimensão contingente e a agência dos sujeitos, oportunizadas principalmente a partir de seus deslocamentos, produtores de significados espaciais.

\section{Referências bibliográficas}

ACHILLES, Nancy. The development of the homosexual bar as an institution. In: Dynes, Wayne R.; Donaldson, Stephen (Eds.). Sociology of homosexuality. New York, Garland Pub, 1992 [1964], pp. 2-18. 
ADERALDO, Guilhermo André. Reinventando a cidade: uma etnografia das lutas simbólicas entre coletivos culturais video-ativistas nas "periferias". São Paulo, Annablume, 2017.

AGIER, Michel. Do direito à cidade ao fazer-cidade. O antropólogo, a margem e o centro. Mana 21 (3). Rio de Janeiro, 2015, pp. 483-498.

AGIER, Michel. Antropologia da cidade: lugares, situações, movimentos. São Paulo, Editora Terceiro Nome, 2011.

BARBOSA DA SiLVA, José Fábio. Homossexualismo em São Paulo: estudo de um grupo minoritário. In: Green, James N.; Trindade, Ronaldo (Orgs.). Homossexualismo em São Paulo e outros escritos. São Paulo, Editora Unesp, 2005 [1960], pp. 41-212.

BRAH, Avtar. Diferença, diversidade, diferenciação. Cadernos Pagu (26). Campinas, 2006, pp. 329-376.

BUTLER, Judith. Problemas de Gênero: feminismo e subversão da identidade. Rio de Janeiro, Civilização Brasileira, 2010.

CALDEIRA, Teresa Pires do Rio. Cidade de muros: crime, segregação e cidadania em São Paulo. São Paulo, Editora 34/Edusp, 2000.

CALDEIRA, Teresa Pires do Rio. A política dos outros: o cotidiano dos moradores da periferia e o que pensam do poder e dos poderosos. São Paulo: Brasiliense, 1984.

CARDOSO, Ruth. Estrutura familiar e mobilidade social. Estudos dos japoneses no estado de São Paulo. São Paulo, Primus, 1972.

CARRARA, Sérgio. A antropologia e o processo de cidadanização da homossexualidade no Brasil. Cadernos Pagu (47). Campinas, 2016, e164717.

CHAMBERS, Ian. Migración, cultura, identidad. Buenos Aires: Amorrortu Editores, 1995.

CORREIA, Ana Paula de Santana. Mulheres da periferia em movimento: um estudo sobre outras trajetórias do feminismo. Dissertação de mestrado, Ciências Sociais, Unifesp, 2015.

CRAPANZANO, Vincent. Estilos de interpretação e a retórica de categorias sociais. In: Maggie, Yvonne \& Rezende, Claudia Barcelos (orgs.). 
"Periferias" móveis: (homo)sexualidades, mobilidades e produção de diferença na cidade de São Paulo

Raça como retórica: a construção da diferença. Rio de Janeiro, Civilização Brasileira, 2001, pp. 443-458.

CRESSWELl, Tim. Seis temas na produção das mobilidades. In: Carmo, Renato Miguel \& Simões, José Alberto (orgs.). A produção das mobilidades: redes, espacialidades e trajectos. Lisboa, Imprensa de Ciências Sociais, 2009, pp. 25-40.

D'EMILIO, John. Capitalism and Gay Identity. In: Abelove, Henry; Barale, Michèle Aina; Halperin, David M. (Eds.). The lesbian and gay studies reader. New York, Routledge, 1993, pp. 467-476.

DURHAM, Eunice. Assimilação e mobilidade - a história do imigrante italiano num município paulista. São Paulo, IEB, 1966.

DURHAM, Eunice. A caminho da cidade: A vida rural e a migração para a cidade de São Paulo. São Paulo, Perspectiva, 1978.

DURHAM, Eunice. A sociedade vista da periferia. Revista Brasileira de Ciências Sociais (1). São Paulo, 1986, pp. 84-99.

EFREM FILHO, Roberto. Mata-mata: reciprocidades constitutivas entre classe, gênero, sexualidade e território. Tese de doutorado, Ciências Sociais, Unicamp, 2017.

FACCHINI, Regina. Entre umas e outras: mulheres (homo)sexualidades e diferenças na cidade de São Paulo. Tese de doutorado, Ciências Sociais, Unicamp, 2008.

FACCHINI, Regina; Daniliauskas, Marcelo; Pilon, Ana Cláudia. Políticas sexuais e produção de conhecimento no Brasil: situando estudos sobre sexualidade e suas conexões. Revista de Ciências Sociais (44). Fortaleza, 2013, pp. 161-193.

FACCHINI, Regina; França, Isadora Lins; Braz, Camilo. Estudos sobre sexualidade, sociabilidade e mercado: olhares antropológicos contemporâneos. Cadernos Pagu (42). Campinas, 2014, pp. 99-140.

FELTRAN, Gabriel de Santis. Fronteiras de tensão: política e violências nas periferias de São Paulo. São Paulo, Editora Unesp/CEM-Cebrap, 2011.

FERREIRA, João Sette Whitaker; Maricato, Ermínia; Villaça, Flávio. O mito da cidade-global: o papel da ideologia na produção do espaço urbano. São Paulo, Vozes, 2007. 
FRANÇA, Isadora Lins. Consumindo lugares, consumindo nos lugares: homossexualidade, consumo e subjetividades na cidade de São Paulo. Rio de Janeiro, EdUERJ, 2012.

FRANÇA, Danilo. Desigualdades e segregação residencial por raça $e$ classe. In: Marques, Eduardo. (org.). A metrópole de São Paulo no século XXI: espaços, heterogeneidades e desigualdades. São Paulo, Ed. Unesp/CEM, 2015, p.223-251.

FRÚGOLI JR., Heitor. Centralidade em São Paulo: trajetórias, conflitos e negociações na metrópole. São Paulo, Cortez/Edusp, 2000.

Frúgoli JR., Heitor. Introdução: dossiê Luz, São Paulo. Ponto Urbe, São Paulo, v. 6, n. 11, São Paulo, 2012 [http://pontourbe.revues.org/79 acesso em 1 de abril de 2016].

FRY, Peter. Da hierarquia à igualdade: a construção histórica da homossexualidade no Brasil. In: Para Inglês Ver: Identidade e Política na Cultura Brasileira. Rio de Janeiro, Zahar, 1982, pp. 87-115.

GuASCO, Pedro Paulo Marques. Num país chamado periferia: identidade e representação da realidade entre os rappers de São Paulo. Dissertação de mestrado, Antropologia Social, USP, 2001.

GuimARÃES, Carmen Dora. O homossexual visto por entendidos. Rio de Janeiro, Garamond, 2004 [1977].

HALl, Stuart. Quem precisa de identidade?. In: Silva, Tomaz Tadeu (org.). Identidade e Diferença: a perspectiva dos Estudos Culturais. São Paulo, Vozes, 2005, pp. 103-133.

KowARICK, Lúcio. A espoliação urbana. Rio de Janeiro, Paz e Terra, 1979.

LEVINE, Martin P. Gay ghetto. In: . Gay Men: The Sociology of Male Homosexuality. New York, Harper \& Row, 1979, pp. 182-204.

LEZNOFF, M.; Westley, W. A. The homosexual community. In: Nardi, P. M.; Schneider, B. E. (Eds.). Social perspectives in lesbian and gay studies: a reader. New York, Routledge, 1998 [1956], pp. 5-11.

MACRAE, Edward. Em defesa do gueto. Novos Estudos CEBRAP. São Paulo, v. 2, n. 1, 1983, pp. 53-60. 
"Periferias" móveis: (homo)sexualidades, mobilidades e produção de diferença na cidade de São Paulo

MAGALHÃES, Liliane Sousa. Participação de jovens em grupos culturais e mobilidade no espaço urbano de São Paulo. Dissertação de mestrado, Sociologia da Educação, USP, 2008.

MAGNANI, José Guilherme Cantor. Festa no pedaço: Cultura popular e lazer na cidade. São Paulo, Hucitec/UNESP, 1998.

MAGNANI, José Guilherme. Da periferia ao centro: trajetórias de pesquisa em Antropologia Urbana. São Paulo, Terceiro Nome, 2012.

MARCUS, George E. e Fischer, Michael M. J. La antropología como crítica cultural. Un momento experimental enlas ciencias humanas. Buenos Aires, Amorrortu editores, 2000 [1986].

MARQUES, Roberto. Cariri eletrônico: paisagens sonoras no nordeste. São Paulo, Intermeios, 2015.

MASSEY, Doreen. Pelo espaço: uma nova política da espacialidade. Rio de Janeiro: Bertrand Brasil, 2013.

MASSEY, Doreen. Um sentido global do lugar. In: Arantes, Antônio (org.). O espaço da diferença. Campinas, Papirus, 2000, pp. 176-185.

MedeIROS, Camila Pinheiro. Mulheres de Kêto: etnografia de uma sociabilidade lésbica na periferia de São Paulo. Dissertação de mestrado, Antropologia Social, UFRJ/MN, 2006.

NASCIMENTO, Érica Peçanha. Literatura marginal: os escritores da periferia entram em cena. Dissertação de mestrado, Antropologia Social, USP, 2006.

NASCIMENTO, Érica Peçanha. É tudo nosso! Produção cultural na periferia paulistana. Tese de doutorado, Antropologia Social, USP, 2011.

OlIVAR, José Miguel Nieto. Devir puta: políticas da prostituição nas experiências de quatro mulheres militantes. Rio de Janeiro, EdUERJ, 2013.

PASSAMANI, Guilherme Rodrigues. Batalha de Confete no "Mar de Xarayés": condutas homossexuais, envelhecimento e regimes de visibilidade. Tese de doutorado, Ciências Sociais, Unicamp, 2015.

PEREIRA, Alexandre Barbosa. A maior zoeira na escola: experiências juvenis na periferia de São Paulo. São Paulo, Editora Unifesp, 2016. 
PERLONGHER, Néstor Osvaldo. O négocio do michê: a prostituição viril em São Paulo. São Paulo, Editora Fundação Perseu Abramo, 2008 [1987].

Piscitelli, Adriana. Apresentação. Cadernos Pagu (42). Campinas, 2014, pp. 07-12.

PISCITELli, Adriana. Trânsitos: brasileiras nos mercados transnacionais do sexo. Rio de Janeiro, EdUERJ, 2013.

POLLAK, Michael. A homossexualidade masculina, ou: a felicidade do gueto?. In: Ariès, Phillipe \& Bejin, André. (orgs.). Sexualidades ocidentais - contribuições para a história e para a sociologia da homossexualidade. São Paulo, Brasiliense, 1985, pp. 54-76.

PRECIADO, Beatriz. Pornotopía: arquitectura y sexualidade en "Playboy" durante la guerra fría. Barcelona, Anagrama, 2010.

PUCCINELLI, Bruno. Se essa rua fosse minha: sexualidade e apropriação do espaço na "rua gay" de São Paulo. Dissertação de Mestrado, Ciências Sociais, EFLCH/Unifesp, 2013.

PuCCINELli, Bruno. Rua declinada no masculino: sexualidades, mercado imobiliário e masculinidades no Centro de São Paulo (Brasil). Punto Género. Chile, n. 6, 2015, pp. 113-126.

PuCCINELli, Bruno. "Perfeito para você, no centro de São Paulo": mercado, conflitos urbanos e homossexualidades na produção da cidade. Tese de Doutorado, Ciências Sociais, IFCH/Unicamp, 2017.

REIS, Ramon. Making out with the city: (homo)sexualities and sociospatial disputes in Brazilian "peripheries". Vibrant, Virtual Braz. Anthr. Brasília, v. 14, n. 3, 2017, pp. 1-22.

REIS, Ramon. Cidades e subjetividades homossexuais: cruzando marcadores da diferença em bares nas "periferias" de São Paulo e Belém. Tese de Doutorado, Antropologia Social, FFLCH/USP, 2016.

RIBEIRO, Luiz Cesar Queiroz \& Lago, Luciana Corrêa. "Reestruturação nas grandes cidades brasileiras: o modelo centro/periferia em questão". Publicação on line do Observatório das Metrópoles, Rio de Janeiro, [http://www.observatoriodasmetropoles.ufrj.br/download/reestruturaca o_cidades.pdf - acesso em 9 de agosto de 2016]. 
"Periferias" móveis: (homo)sexualidades, mobilidades e produção de diferença na cidade de São Paulo

SASSEN, Saskia. A cidade global. In: Lavinas, Lena; Carleial, Liana Maria da Frota; NABUCO, Maria Regina. Reestruturação do espaço urbano e regional no Brasil. São Paulo, ANPUR/Hucitec, 1993, pp. 187-202.

SIMÕES, Júlio Assis \& França, Isadora Lins. Do "gueto" ao mercado. In: Green, James \& Trindade, Ronaldo (rgs.). Homossexualismo em São Paulo e outros escritos. São Paulo, Editora UNESP, 2005, pp. 309336.

SIMÕES, Júlio Assis; França, Isadora Lins; Macedo, Marcio. Jeitos de corpo: cor/raça, gênero, sexualidade e sociabilidade juvenil no centro de São Paulo. Cadernos Pagu (35). Campinas, 2010, pp. 37-78.

SIMÕES, Júlio Assis. Marcadores de diferença na "comunidade" LGBT: raça, gênero e sexualidade entre jovens do centro de São Paulo. In: Colling, Leandro (org.). Stonewall $40+$ o que no Brasil?. Salvador, EDUFBA, 2011, pp. 157-173.

TALHARI, Julio; Silveira, Laís; Puccinelli, Bruno. "Reflexões em torno de práticas culturais na Luz". Ponto Urbe [Online], 11 | 2012, posto online no dia 01 dezembro 2012, consultado o 17 dezembro 2018. URL : http://journals.openedition.org/pontourbe/1151; DOI : 10.4000/pontourbe. 1151

TELLES, Vera da Silva. A cidade nas fronteiras do legal e do ilegal. Belo Horizonte, Argumentvm, 2010.

TElles, Vera da Silva. Anos 70: experiências, práticas e espaços políticos. In: Kowarick, Lúcio. As lutas sociais e a cidade: São Paulo passado e presente. Rio de Janeiro, Paz e Terra, 1994, pp. 217-249.

VIEZZER, Moema. O problema não está na mulher. São Paulo, Cortez, 1989.

WARREN, Carol. Space and time. In: Nardi, P. M.; Schneider, B. E. (Eds.). Social perspectives in lesbian and gay studies: a reader. New York, Routledge, 1998 [1974], pp. 183-193.

ZALUAR, Alba. A máquina e a Revolta: as organizações populares e o significado da pobreza. São Paulo, Brasiliense, 1985. 